\title{
Comparative Acute Toxicity of Five Insecticide against Rice Weevil
}

ISSN: 2637-7659

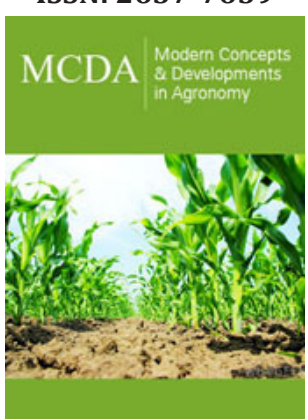

*Corresponding author: Hamdy $\mathrm{R}$ Soltan,Department of Pesticide chemistry and Technology, Faculty of Agriculture, Alexandria University, Alexandria, Egypt

Submission: March 05, 2020

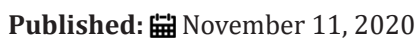

Volume 7 - Issue 3

How to cite this article: Hamdy R Soltan, Ahmed S ElBakary, Mohamed S Shawir, Turki AlHomudi. Comparative Acute Toxicity of Five Insecticide against Rice Weevil. Mod Concep Dev Agrono. 7(3). MCDA. 000665. 2020. DOI: 10.31031/MCDA.2020.07.000665

Copyright@ Hamdy R Soltan, This article is distributed under the terms of the Creative Commons Attribution 4.0 International License, which permits unrestricted use and redistribution provided that the original author and source are credited. Hamdy $\mathbf{R}$ Soltan $^{1 *}$, Ahmed S ElBakary ${ }^{1}$, Mohamed S Shawir ${ }^{1}$ and Turki
AlHomudi

${ }^{1}$ Department of Pesticide chemistry and Technology, Faculty of Agriculture, Alexandria University, Alexandria, Egypt

${ }^{2}$ Ministry of Agriculture, KingdomSaudi Arabia

\begin{abstract}
The effect of two temperatures $(20 \mathrm{oC}$ and $30 \mathrm{oC})$ on the toxicity of deltamethrin, and pirimiphos methyl against Sitophilus oryzaewere studied using the residual film method. Results revealed that mortality increased proportionally with an increase in temperature, where the optimum temperature for toxicity of both tested insecticides was $30^{\circ} \mathrm{C}$ either the mortality recorded at 24 or 48 hours after treatment. The insecticidal efficacy of five contact insecticides was also compared against Sitophilus oryzae(deltamethrin, imidacloprid, abamectin, emamectin benzoate and pirimiphos methyl at $30 \mathrm{oC}$ temperature. Mortality of tested insecticides against rice weevils was recorded at $30^{\circ} \mathrm{C}$ after 24 and 48 hours of exposure. Among the insecticides, deltamethrin was the most effective insecticide against rice weevils with median lethal concentration ranging from 0.48 to $0.35 \mathrm{ppm}$ followed by abamectin 0.682 to 0.399 and pirimiphos methyl with LC500.472 to $0.85 \mathrm{ppm}$ at 24 and 48 hoursexposure periods, respectively. On the other hand, the other insecticides (emamectin benzoate and imidachloprid) were in-between according to the median lethal concentration recorded.
\end{abstract}

Keywords: Pirimiphos-methyl; Mammals; Organophosphorus; Emamectin benzoate; Sitophilus oryzae

\section{Introduction}

Rice weevil, Sitophilus oryzae (L.) (Coleoptera: Curculionidae), is one of the most destructive pests of stored cereals and processed cereal products worldwide. It is classed as a primary pest, one which can easily infest sound cereal seeds [1-3]. Control of this pest two categories of insecticides are usually applied: fumigants and residual grain protectants. Over the past few decades, the fumigants phosphine and methyl bromide have come to play a significant part in controlling S.oryzae and other stored-product pests. However, a phase-out of methyl bromide has already started, because this substance is considered as a contributor to the reduction of the ozone layer [4,5]. In addition, many stored-product pests, including rice weevil, have developed resistance to phosphine, due to its wide application [6]. This situation could result in residual insecticides becoming the dominant control measure against stored-cereal pests. Moreover, grain protectants

(a) can be applied easily without specialized equipment,

(b) are compatible with international cereal trade and global restrictions for zero insect tolerance,

(c) are generally less expensive than fumigants or biopesticides and

(d) are effective against a wide range of storage pests [7].

Therefore, it is likely that grain protectants will continue to constitute a valuable tool in pest management programs [7-9]. A large number of pesticides are in common use as grain protectants $[10,11]$. These insecticides protect the grain aginst the attack of pests trying to fix themselves into the grain mass.

Traditional organophosphates, such as malathion and pirimiphos-methyl are the most commonly used residual insecticides in stored wheat [7]. Also, pyrethroids have proved to be successful alternatives to traditional organophosphorus insecticides, given that they are costeffective and generally less toxic to mammals. 
However, Sitophilus spp. has rapidly developed a considerable level of resistance to organophosphorus and pyrethroids grain protectants $[6,7,12]$.

The current work is an investigation into the possibility of using several contact insecticides to control Sitophilus oryzae (L). Therefore, the present study was conducted to compare the effect of pirimiphos-methyl, deltamethrin, imidacloprid, emamectin benzoate and abamectin which belong to different insecticide groups, on Sitophilus oryzae.

\section{Material and Methods}

\section{Source and rearing of $S$. oryzae (L.) culture}

Adults of the rice weevil, Sitophilus oryzae (L.) were reared in the laboratory as previously described by [13]. The initial stock of $S$. oryzae was obtained from infested wheat. Insects were mass produced in a climatized chamber at $27 \pm 1 \mathrm{C}$ and $70 \pm 5 \%$ r.h. with alternating light \pm dark cycles of $12 \mathrm{~h}$. Insects were maintained in glass jars (0.25L capacity) with $200 \mathrm{~g}$ of wheat free from pesticides. The jars were covered with a muslin cloth and after 2 weeks the original adults were removed by sieving. Once new adult weevils started to emerge, each jar was observed daily to collect the progeny which were kept in separate jars, according to their age group. Under these conditions, the period from egg lay to adult emergence was about 5 weeks. Adult insects (2-3 weeks after emergence were used for experimental work.

\section{Bioassay of insecticides:}

Laboratory-reared adult insects (2-3 weeks old) were used for this study. The weevils were collected from rearing jars, placed in a Petri dish and mixed thoroughly to facilitate random selection of the insects. Five replicates were made for each insecticide concentration tested. Insecticides effectiveness against rice weevil adults from the laboratory population was determined after applying a series of concentrations of each commercial product via surface deposit application on Petri-dishes ( $9 \mathrm{~cm}$ i.d.) using a method described by Moustafa et al. [14]. The treatments consisted of five concentrations of each of primiphos-methyl ranged (0.1$4 \mathrm{ppm})$, emamectin benzoate (0.01-1ppm), imidachloprid (0.1$6 \mathrm{ppm})$, abamectin (0.01-1ppm), and deltamethrin (0.1-0.8ppm). One $\mathrm{ml}$ of diluted insecticide solution (diluted with acetone), at the selected concentrations, was applied on the surface of the Petridishes and then allowed to dry for approximately half an hour before use. Twenty adults (2-3 weeks old) were transferred to each Petri-dish, confined by plastic rings, incubated at $30{ }^{\circ} \mathrm{C}$ and the mortality was recorded 1 and 2 days later. Also, another two groups of Petri dishes contained deltamethrin and pirimiphos-methyl insecticides were kept at two different temperatures $\left(20\right.$ and $\left.30{ }^{\circ} \mathrm{C}\right)$ and the mortality was recorded at the same manner. All data were corrected by Abbott's WS [15]. The $\mathrm{LC}_{50}$ values as (ppm), slopes and their confidence limits were calculated according to Finney [16].

\section{Results and Discussion}

\section{Effect of temperature on toxicity of insecticides to Sitophilus oryzae}

Impregnated filter paper technique was used to evaluate the toxicity of pirimiphos-methyl to $S$. oryzae at two different temperatures $20^{\circ} \mathrm{C}$ and $30{ }^{\circ} \mathrm{C}$. The adult of $S$. oryzae was exposed to the residue of pirimiphos-methyl for $24 \mathrm{~h}$. Mortality was recorded for both temperature and parameters of toxicity were estimated which include $\mathrm{LC}_{50}$, slope and their confidence limits beside the regression equations and Ld-p line was presented in (Table 1).

Table 1: Toxicity of Pirimiphos-methyl and deltamethrin insecticides to Sitophilus oryzea adults at 20 and $30{ }^{\circ} \mathrm{C}$ after 24 hours exposure time.

\begin{tabular}{|c|c|c|c|c|}
\hline Temperature & $\begin{array}{l}\text { LC }_{50} \text { (Confidence Limits) } \\
\text { (ppm) Lower-Upper }\end{array}$ & Slope & Slope \pm SE & Regression Equation \\
\hline \multicolumn{5}{|c|}{ Pirimiphos-methyl } \\
\hline $20^{\circ} \mathrm{C}$ & $1.78(1.01-2.56)$ & 1.1 & 0.12 & $\mathrm{Y}=0.27+1.10 \mathrm{X}$ \\
\hline $30^{\circ} \mathrm{C}$ & $0.85(0.90-1.73)$ & 0.95 & 0.11 & $Y=0.07+0.95 X$ \\
\hline \multicolumn{5}{|c|}{ Deltamethrin } \\
\hline $20^{\circ} \mathrm{C}$ & $1.42(0.42-2.91)$ & 1.02 & 0.2 & $Y=0.16+1.02 X$ \\
\hline $30^{\circ} \mathrm{C}$ & $0.48(0.35-0.70)$ & 1.95 & 0.21 & $Y=0.68+1.54 X$ \\
\hline
\end{tabular}

Since the $\mathrm{LC}_{50}$ value at $30{ }^{\circ} \mathrm{C}(0.85 \mathrm{ppm})$ was less than that at $20{ }^{\circ} \mathrm{C}(1.78 \mathrm{ppm})$ which revealed that the toxicity increased with increasing temperature for tested temperatures (Figure 1). Also, the toxicity of deltamethrin against $S$. oryzae expressed as $\mathrm{LC}_{50}$ was increased with an increasing temperature from $1,42 \mathrm{ppm}$ at $20^{\circ} \mathrm{C}$ to $0.48 \mathrm{ppm}$ at $30{ }^{\circ} \mathrm{C}$ (Figure 2). Generally, our results were not in line with some earlier findings by the previous research carried out by Subramanyam and Hagstrum [17]; Fleurat-Lessard et al. [18]. Both researchers pointed out that the research of storage insects has revealed that organophosphate compounds are more toxic at temperatures $30^{\circ} \mathrm{C}$, and pyrethroids at $20^{\circ} \mathrm{C}$. 


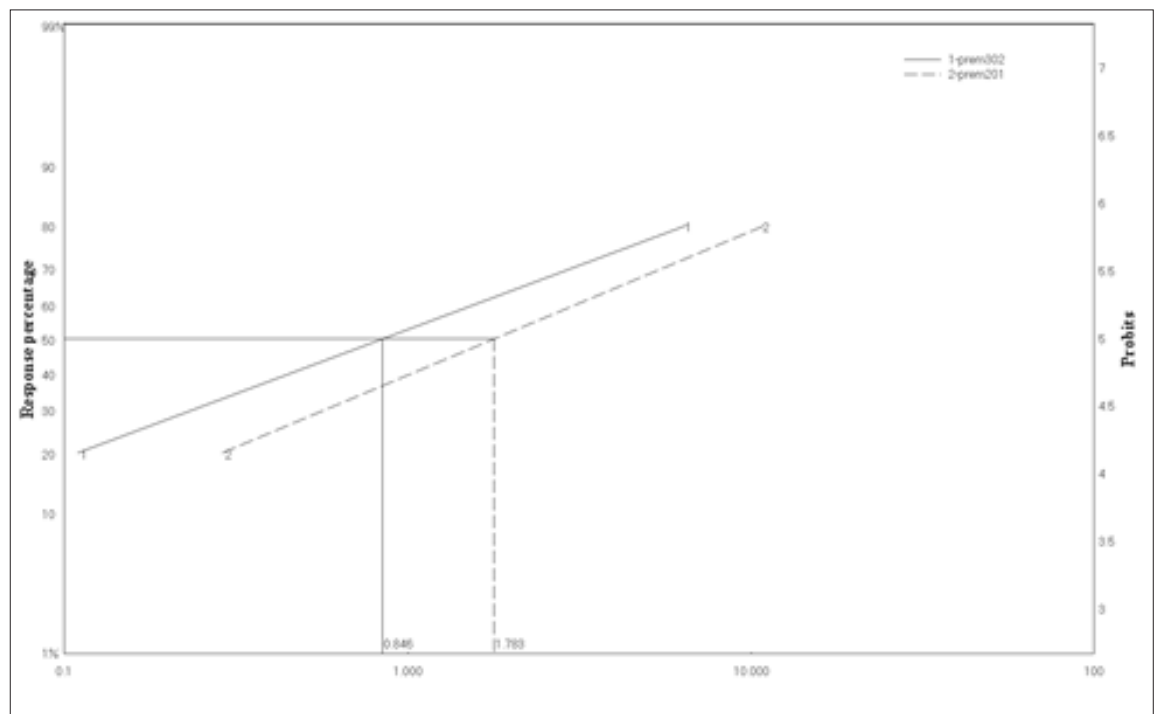

Figure 1: Ld-P line of pirimiphos methyl bioassayed against S. oryzae after $24 \mathrm{hr}$ of exposure at 20 and $30{ }^{\circ} \mathrm{C}$.

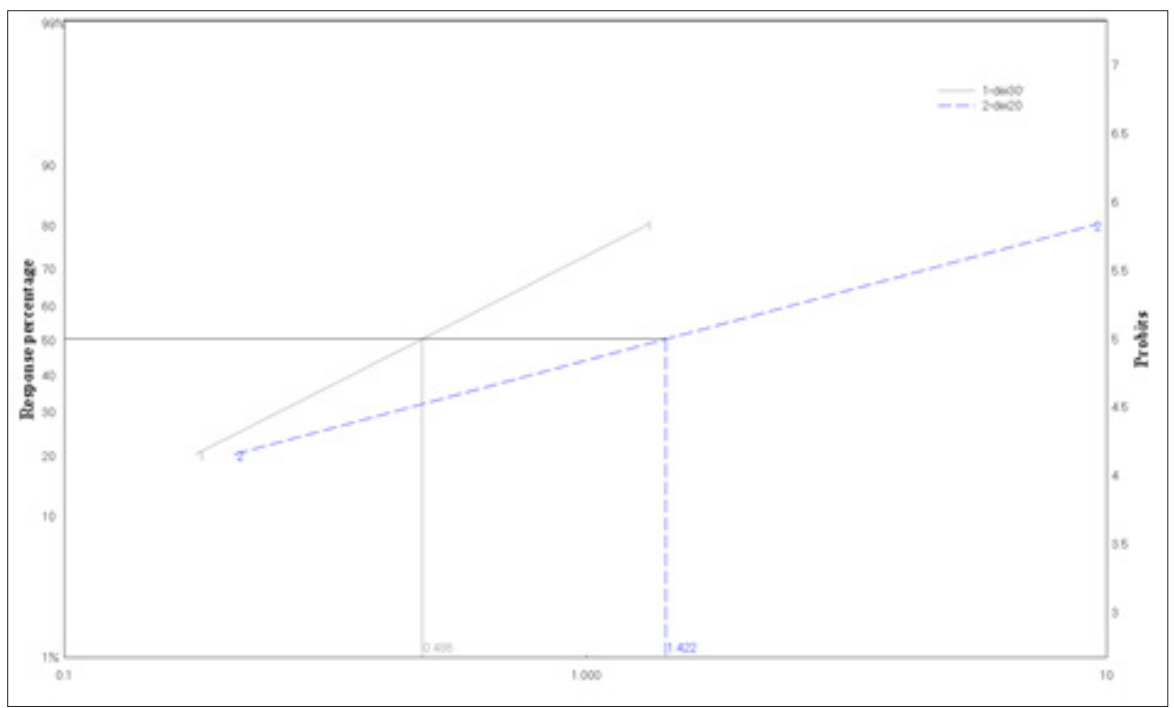

Figure 2: Ld-P line of deltamethrin bioassayed against S. oryzae after $24 \mathrm{hr}$ of exposure at 20 and 30 oC.

Comparing the toxicity of pirimiphos-methyl and deltamethrin to the adult of weevil at the same temperature, deltamethrin was more effective, since the $\mathrm{LC}_{50}$ was 1.42 and $0.48 \mathrm{ppm}$ while it was 1.78 and $0.85 \mathrm{ppm}$ for pirimiphos-methyl at 20 and $30{ }^{\circ} \mathrm{C}$, respectively [19]. The $\mathrm{LC}_{50}$ values at $30{ }^{\circ} \mathrm{C}$ could be attributed to increasing the active ingredient penetration rate of insecticide throughout the cuticle of $S$. oryzae or/and increasing the activities of the adult weevils at the high temperature that allowed the adults weevil pick up more insecticides

\section{Effect of the exposure time on toxicity of five insecticides to adult of $S$. oryzae.}

Five insecticides belong to different groups of insecticides were evaluated for their toxicity to $S$. oryzae using impregnated filter paper technique of bioassay at $30{ }^{\circ} \mathrm{C}$. Mortality of weevil was recorded after $24 \mathrm{~h}$ and $48 \mathrm{~h}$ of exposure to the residues of insecticides. The parameters of toxicity was presented in (Table $2 \& 3$ ) and the Ld-plines (Figure 3\&4). The results in terms of $\mathrm{LC}_{50}$ showed that the deltamethrin was the most effective insecticides whereas $\mathrm{LC}_{50}$ value was $0.48 \mathrm{ppm}$ followed with abamectin $0.682 \mathrm{ppm}$, pirimiphos-methyl $0.85 \mathrm{ppm}$ and emamectin benzoate $1.088 \mathrm{ppm}$ whereas, imidacloprid was the less toxic one among the tested insecticides with $\mathrm{LC}_{50} 1.8 \mathrm{ppm}$ against $S$. oryzae at 30 ${ }^{\circ} \mathrm{C}$ for $24 \mathrm{hr}$ exposure time. Also, the toxicity trend was increased with an increasing of the exposure time from $24 \mathrm{hr}$. to $48 \mathrm{hr}$. for all the insecticides tested against the adults of rice weevils at the same temperature. The $\mathrm{LC}_{50}$ could be arranged to the descending order as fellow: deltamethrin $0.35 \mathrm{ppm} \geq$ abamaction $0.399 \mathrm{ppm}>$ pirimiphos-methyl= emamectin benzoate $0.58 \mathrm{ppm}>$ Imidachloprid $0.68 \mathrm{ppm}$. 
Table 2: Toxicity of insecticides to Sitophilus oryzea adults at $30{ }^{\circ} \mathrm{C}$ after 24 hours of exposure using impregnated filter paper technique.

\begin{tabular}{|c|c|c|c|c|}
\hline Insecticide & $\begin{array}{c}\mathbf{L C}_{50} \text { (Confidence Limits) (ppm) } \\
\text { Lower Upper }\end{array}$ & Slope & Slope \pm SE & Regression Equation \\
\hline Pirimiphos methyl & $0.85(0.90-1.73)$ & 0.95 & 0.11 & $\mathrm{Y}=0.07+0.95 \mathrm{X}$ \\
\hline Emamectin benzoate & $1.088(0.60-3.97)$ & 1.04 & 0.15 & $\mathrm{Y}=0.04+1.04 \mathrm{X}$ \\
\hline Imidachloprid & $1.8(1.251-2.80)$ & 1.833 & 0.17 & $\mathrm{Y}=0.48+1.83 \mathrm{X}$ \\
\hline Abamectin & $0.68(0.29-2.21)$ & 0.9 & 0.1 & $\mathrm{Y}=0.15+0.92 \mathrm{X}$ \\
\hline Deltamethrin & $0.48(0.70-0.35)$ & 1.95 & 0.21 & $\mathrm{Y}=0.69+1.95 \mathrm{X}$ \\
\hline
\end{tabular}

Table 3: Toxicity of insecticides to Sitophilus oryzea adults at $30{ }^{\circ} \mathrm{C}$ after 48 hours of exposure using impregnated filter paper technique.

\begin{tabular}{|c|c|c|c|c|}
\hline Insecticide & $\begin{array}{c}\mathbf{L C}_{50} \text { (ppm) } \\
\text { (Confidence Limits) Lower- Upper }\end{array}$ & Slope & Slope \pm SE & Regression Equation \\
\hline Primiphos-methyl & $0.58(1.04-0.25)$ & 1.44 & 0.11 & $Y=0.04+1.44 \mathrm{X}$ \\
\hline Emamectin benzoate & $0.58(1.262-0.316)$ & 1.252 & 0.15 & $Y=0.292+1.25 \mathrm{X}$ \\
\hline Imidachloprid & $0.68(1.033-0.421)$ & 1.696 & 0.17 & $Y=0.27+1.69 \mathrm{X}$ \\
\hline Abamectin & $0.399(1.052-0.119)$ & 0.741 & 0.1 & $Y=0.339+0.74 \mathrm{X}$ \\
\hline Deltamethrin & $0.35(0.525-0.247)$ & 1.65 & 0.21 & $Y=0.734+1.65 \mathrm{X}$ \\
\hline
\end{tabular}

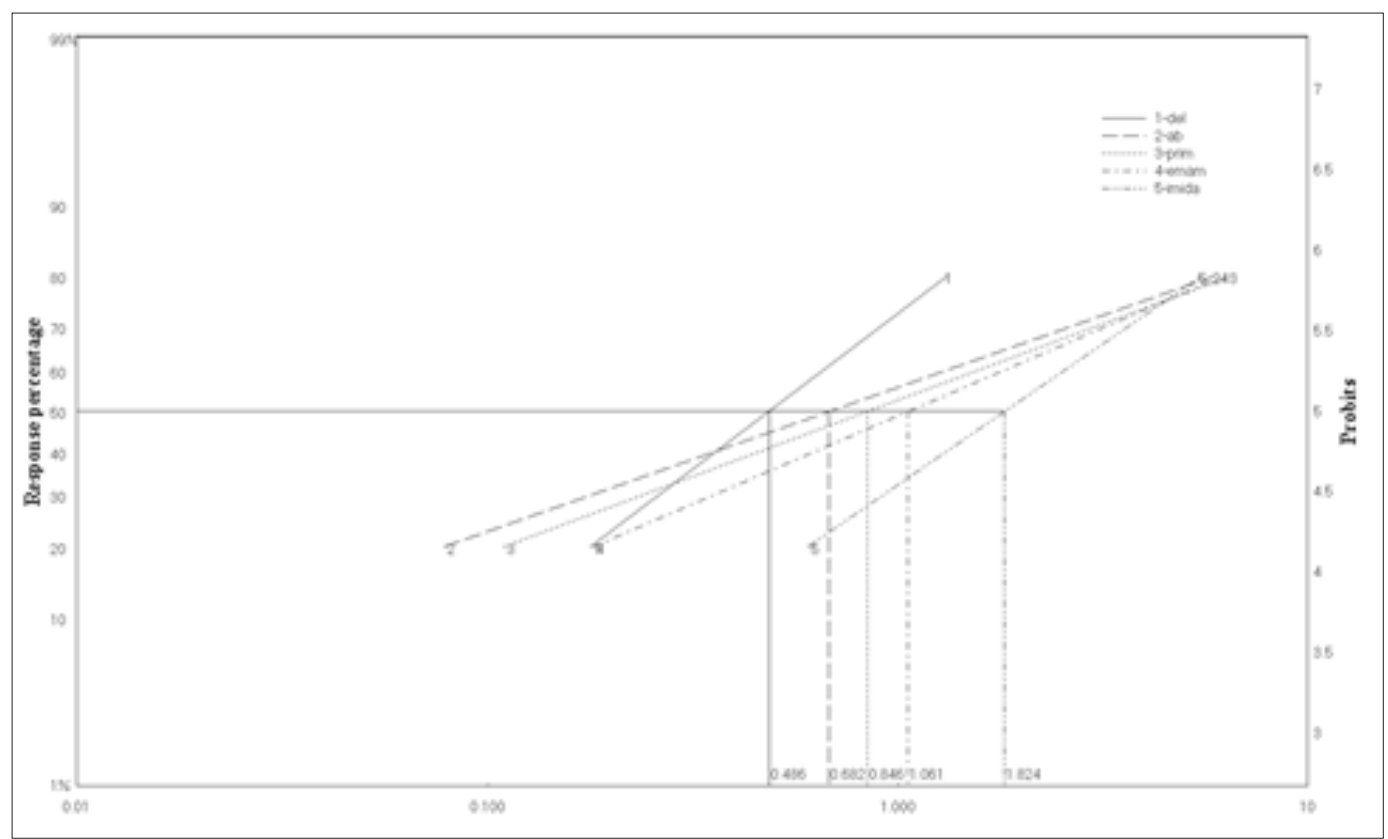

Figure 3: Ld-P line of Pirimiphos methyl, Emamectin benzoate, imidachloprid, deltamethrin and abamectin bioassayed against S. oryzae after $24 \mathrm{hr}$ of exposure. 


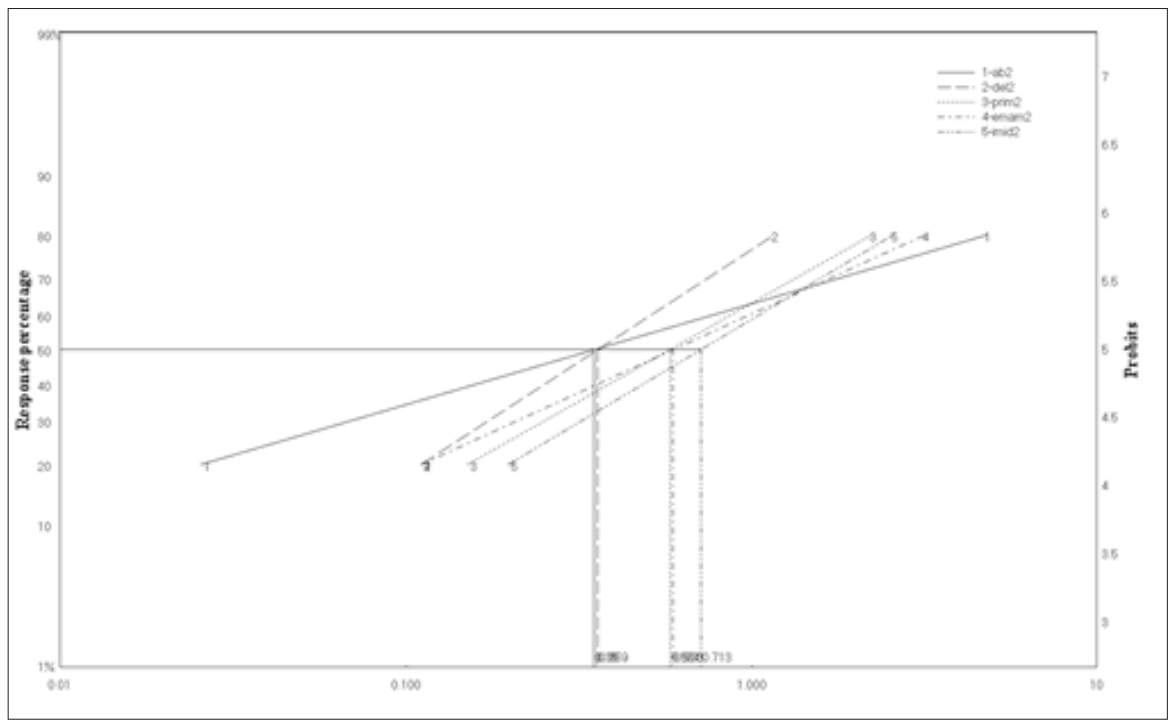

Figure 4: Ld-P line of Pirimiphos methyl, emamectin benzoate, imidachloprid, deltamethrin and abamectin bioassayed against $\mathrm{S}$. oryzae after $48 \mathrm{hr}$ of exposure.

\section{References}

1. Hill DS (1990) Pests of stored products and their control. Belhaven Press, London, pp. 8-55.

2. Rees D (2004) Insects of stored products. CSIRO Publishing Australia and Manson Publishing Ltd., UK.

3. Mason LJ, McDonough M (2012) Biology behavior, and ecology of stored grain and legume insects. Hagstrum DW, Philips TW, Cuperus G (Eds.), Stored Product Protection, Kansas State University Agricultural Experiment Station and Cooperative Extension Service, Kansas, USA, pp. 7-20.

4. WMO (1995) Scientific assessment of ozone depletion: World Meteorological Organization global ozone research and monitoring project. Report No. 37, WMO, Geneva, Switzerland.

5. Shaaya E, Kostjukovski M, Eilberg J, Sukprakarn C (1997) Plant oils as fumigants and contact insecticides for the control of stored-product insects. Journal of Stored Products Research 33(1): 7-15.

6. Georgiou GP (1991) The occurrence of resistance to pesticides in arthropods. FAO, Rome, Italy, p. 318.

7. Arthur FH (1996) Grain protectants: current status and prospects for the future. Journal of Stored Products Research 32(4): 293-302.

8. White NDG, Leesch JG (1995) Chemical control. In: Subramanyam B, Hagstrum DW (Eds.), Integrated Management of Insects in Stored Products. Marcel Dekker, New York, USA, pp. 287-330.

9. Arthur FH (2012) Aerosols and contact insecticides as alternatives to methyl bromide in flour mills, food production facilities, and food warehouses. J Pest Sci 85: 323-329.

10. Daglish GJ, Wallbank BE, Nayak MK (2003) Synergized bifenthrin plus chlorpyriphos-methyl for control of beetles and psocids (Psocoptera:
Liposcelididae) in sorghum in Australia. J Econ Entomol 96(2): 525-532.

11. Nayak MK, Daglish GJ (2006) Potential of imidacloprid to control four species of psocids (Psocoptera: Liposcelididae) infesting stored grain. Pest Manag Sci 62(7): 646-650.

12. Boyer S, Zhang H, Lempérière G (2012) A review of control methods and resistance mechanisms in stored-product insects. Bull Entomol Res 102(2): 213-229.

13. El Kashan IH (1984) Studies on some stored products insects. M.Sc. Thesis, Faculty of Agriculture, Alexandria University, Egypt.

14. Moustafa FI, El Sebae AH, El Hawashi, NS Zeid MI (1980) Toxicity of seven organophosphorus insecticides to the confused four beetle; Tribolium Confusum (Duv.) applied by to differentt methods. Alex J Agric Res 28(3): 273-277.

15. Abbott WS (1925) A method of comparing the effectiveness of an insecticide. J Econ Entomol 18: 265-267.

16. Finney DJ (1971) Probit analysis. ( $\left.3^{\text {rd }} e d n\right)$, Cambridge University press, Cambridge, UK, p. 318.

17. Subramanyam Bh, Hagstrum DW (1996) Resistance measurement and management. In: Subramanyam Bh, Hagstrum DW (Eds.), Integrated Management of Insects in Stored Products. Marcel Dekker, New York, USA, pp. 331-397.

18. Fleurat Lessard F, Vidal M, Budzinski H (1998) Modelling biological efficacy decrease and rate of degradation of chlorpyrifos-methyl on wheat stored under controlled conditions. J Stored Prod Res 34(4): 341354 .

19. Daglish GJ (1998) Efficacy of six grain protectants applied alone or in combination against three species of coleoptera. J Stored Prod Res 34(4): 263-268.

For possible submissions Click below: 